\title{
Aile Kurumuna Yönelik Tehditlerin Farklı Kültürel Deneyimler Açısından Sosyolojik İncelemesi
}

\author{
DOI: $10.26466 /$ opus. 812891
}

*

\begin{abstract}
Ayșegül Demir*
* Dr. Öğr. Üyesi, Sinop Üniversitesi, Fen Edebiyat Fakültesi, Sosyoloji Bölümü, Sinop/Türkiye E-Posta: ayseguldemir@sinop.edu.tr ORCID: 0000-0002-7328-4492

\section{Öz}

Bu çalışmada, aile kurumuna yönelik tehditlerin farklı kültürel deneyimler açısından sosyolojik incelemesinin TRTBELGESEL'de yayınlanmış olan "Aile Olmak" başlıklı belgesel serisi örneği üzerinden yapılması hedeflenmektedir. Çalışmanın yöntemi olarak sosyolojik araştırmada sıklıkla kullanılan niteliksel-yorumsal çözümlemenin klasik bir alan olarak görsel doküman analizi tekniğinin kullanılması uygun görülmektedir. Çalışmanın örneklemini TRTBELGESEL'de yayımlanan ve toplamda 11 (on bir) adet birbirinden farklı konular işlenen belgesel serisi oluşturmaktadır. Her bir belgeselin konusu birbirinden farklı ailelerin toplumsal gerçeklik üzerine inşa edilen gündelik yaşamlarındaki sosyal-ekonomikkültürel deneyimlerin işlendiği ana temaları kapsamaktadır. Çalışmada bu ana temalar, birincisi "gurbetçi"; ikincisi "mülteci, mekân, engellilik, travma, să̆lık, yetersiz beslenme, yoksulluk, tek ebeveynlik"; üçüncüsü "niteliksiz işgücü"; dördüncüsü "yerleşim, ulaşım, kuraklık, tarım, hayvancllık, yerleşim, ulaşım, sağlik, yaşlllık, zanaat, sermaye, eğitim, firsat eşitsizliği"; beşincisi "savaş, göç, iletişim"; altıncısı "emperyalizm, turizm, kültürel yozlaşma, değerler, eşitsizlik"; yedincisi "balık besiciliği, kapitalizm, gündelik yaşam"; sekizincisi "çocukluk", dokuzuncusu "göçebelik, kent, gelenekler"; onuncusu "işgal, yoksulluk, sömürü"; on birincisi "çocuk hizmetleri, darbe, tarih, haberleşme, mektup, duygular, dil" olmaktadır. Sonuç olarak, çalışmanın bulguları doğrultusunda elde edilen konular ve bu konulara ilişkin ana temalar nitel araştırma teknikleri aracılığıyla sosyolojik olarak anlamlandırllmış, betimlenmiş, yorumlanmış ve değerlendirilmiştir.

Anahtar Kelimeler: Aile, Gündelik Yaşam, Toplumsal Gerçekliğin İnşası, Doküman Analizi. 


\title{
Sociological Analysis of Threats Against Family Institution in Terms of Different Cultural Experiences
}

\begin{abstract}
In this study, it is aimed to examine the sociological analysis of the threats against the family institution in terms of different cultural experiences through the example of the documentary series titled "Being a Family" published in TRTBELGESEL. It is considered appropriate to use the visual document analysis technique as a classical field of qualitative-interpretive analysis, which is frequently used in sociological research as the method of the study. The sample of the study consists of a total of 11 (eleven) documentary series published in TRTBELGESEL, which deals with different topics. The subject of each documentary covers the main themes of different families' social-economic-cultural experiences in their daily lives built on social reality. These main themes in the study are the first of them "expatriate"; the second is "refugee, space, disability, trauma, health, malnutrition, poverty, single parenthood"; third, "unqualified labor force"; the fourth is "settlement, transportation, drought, agriculture, animal husbandry, settlement, transportation, health, old age, craft, capital, education, inequality of opportunity"; the fifth is "war, immigration, communication"; sixth "imperialism, tourism, cultural degeneration, values, inequality"; the seventh is "fish farming, capitalism, everyday life"; eighth is "childhood", the ninth is "nomadism, city, traditions"; the tenth is "occupation, poverty, exploitation"; the eleventh is "child services, coup, history, communication, letter, emotions, language". As a result, the topics obtained in line with the findings of the study and the main themes related to these issues are sociologically meaningful, described, interpreted and evaluated through qualitative research techniques.
\end{abstract}

Keywords: Family Institution, Daily Life, Construction of Social Reality, Document Analysis. 


\section{Giriş}

Aile, "insan soyunu sürdürmek üzere iki farklı cins arasında kurulan, evlilik bağıyla başlayan, birincil ilişkilere dayanan, bu arada cinsel ilişkilere meşruiyet kazandıran, soy ve akrabalık düzeyleriyle toplumsal bir boyut taşıyan, soyut bir ilişkiler ağı olması itibariyle kültürel bir kurum; ama nesnel insanlardan oluşması itibariyle fiili bir gruptur"' (Sarı, 2014, s.20).

Aile, tarihsel süreçte geçmişten günümüze kadar toplumların her dönemde bir alt sistemi şeklinde yapılandırılmıştır. İçinde bulunulan topluma göre yapılandırılan bu alt sistemde, gündelik yaşam eksenli aile içi ilişki ve etkileşimler toplumun kültürel değerler ve norm dizgelerine göre biçimlenmektedir. Hatta modern sanayi toplumlarmda ve sanayi öncesi geleneksel toplumların tümünde aile, toplumun temel kurumu olarak belirmektedir. Dönemin egemen olduğu değerler sistemi, aile kurumunun içinde yaşanılan topluma göre toplumsal gerçekliğin inşa ettiği ilişki, etkileşim ve iletişim biçimlerini yapılandırmakta ve düzenlemektedir (Önür, 2013, s.122).

Toplumsal gerçeklik, toplum tarafından inşa edilen amaçlar doğrultusunda bireylerin bu amaçları anlaşılabilir bir şekilde görmesinin bir biçimini temsil eder. Öyle ki bu gerçekliğin karmaşık yapısının çözümlenebilmesinin nedeni, onun hafif ve görülmez özellikte olmasından kaynaklıdır. Bu karmaşık yapı, bireylerin yaşantılarında kurdukları iletişim ağlarıyla birlikte var olan etkileşimde ortaya çıkan çıkarlar, niyetler ve amaçların ne şekilde ve nasıl olduğunu kapsayıcı bir şekilde sunar (Searle, 2005 s.17-51).

Aile kurumu bu toplumsal gerçeklik içerisinde toplumsal düzen, bireyin sosyalizasyonu, mahremiyet ve özel sınırların korunması gibi özellikleriyle pek çok açıdan değişmektedir. Ortaya çıkan bu değişimin meydana getireceği sonuçları tahmin etmek belirsiz olabilir. Ancak sosyal, ekonomik, politik konulardaki dış baskılar ya da tehditler olsa dahi aile kurumunun dış baskılara karşı büyük bir direnç gösterek tüm sosyal kurumları da içine alan bir ağ etrafında gücünü göstererk varlığını tüm gücüyle idame ettirmeye çalışmaktadır (Subaşı, 2014, s.113-115).

Aile Kurumu, bu işlevsel döngü içerisinde toplumda konumlanmış ve hem yeri hem önemi açısından oldukça sağlam dayanağı olan, diğer kurumlarla birebir ilişkiselllik bağı üzerine kurulan toplumsal yapının bir parçasını oluşturmaktadır. Aile olmak ise, gündelik yaşam içerisinde üyelerinin statü ve rollerini kapsayan tüm işlevleri ile ilişkili olmakta ve kültürel farklllıklar 
ve deneyimlerin de etkisiyle sahip oldukları haklar bazında çeşitli toplumlarda yükümlülükleri farklılaşabilmektedir. Bu yönde beliren kurumsal olgular, aile olmanın sorumlulukları gereğince doğayla ve toplumla bir mücadele alanı oluşturmakta ve kendi baş etme stratejileri doğrultusunda bireylere bir yaşantı alanı inşa etmenin önünü açmaktadır.

Gündelik yaşam, bireylerin doğayla dönüştürücü bir praksis içine girdiği, yoldaşlığı ve aşkı öğrendiği, iletişimsel becerileri geliştirdiği bir alandır. Ayrıca, normatif kavramları pragmatik bir şekilde formüle uyguladı̆̆ı, çok çeşitli arzuları, acıları ve duyguları hissettiği ve ne olursa olsun sonunda sönümlendiği bir hayati önemi temsil eden çevre anlamını da ifade etmektedir. Kısaca ifade etmek gerekirse gerek gündelik gerekse kolektif manada bireylerin çok yönlü becerilerini geliştirdiği ve tamamıyla bütünleşip gerçek manada insan olunduğuna ilişkin deneyimlerin toplumsal ilişkiler geliştirilerek yaşandığı ortamdır (Gardiner, 2016, s.14-15).

Toplumsal ilişkiler, mevcut olan sosyal, kültürel, ekonomik ve biyo-fiziksel bağlamlarda insanın beyni, zihni ve insan organizmasının tümü arasındaki sayılamayan etkileşimlerden ve bu etkileşimlerle beraber söz konusu düzeylerin altında yatan süreçlerden meydana gelmektedir. Bu ilişkilerin varlığııı mümkün kılan insan doğasına ilişkin ağları, içkin ilişkisellik hususunda toplumsal bilincin gizemi hakkında söylenenleri ve yaşananları daha iyi görmek ve anlamak gerekmektedir (McFarlane, 2013, s.117).

Toplumsal hareketlilik ve üyelerin toplumsal veya ekonomik anlamda birbirlerine bağlı ağlar, ilişkisellik etrafında toplumsal yükümlülüklerin uygulanmasında etkili mekanizmalar olduğunun altını çizen bir simgesel göstergedir. Bu yönde bir iletişim ağına aidiyeti olan birey, etkileşimi sadece sembolik mübadeleler bakımından değil, aynı zamanda malların ve hizmetlerin mübadelesi açısından da başka bireylere bağımlı bir şekilde gerçekleştirmektedir. Bireylerin arasındaki bu ağlardaki konumun korunması, hem var olan yaşantının tüm haklarından yararlanılması hem de buna karşın yükümlülüklerin yerine getirilmesi ile mümkün olmaktadır (De Landa, 2006, s.249).

Bu çalışmada, kuramsal açıdan Sosyal İnşacı Yaklaşım'ın "gündelik yaşam” ve kültür kavramları odak noktası olarak ele alınmıştır. Aile kurumuna yönelik tehditlerin farklı kültürel deneyimler açısından incelemesi, TRTBELGESEL'de yayınlanmış olan “Aile Olmak” adlı belgesel serisi aracılığıyla ni- 
teliksel yorumlama kullanılarak incelenmektedir. Çalışmadan elde edilen veriler doğrultusunda bulgular önce demografik özelliklerine göre ayrılmış ve sonrasında belgesel serisini oluşturan on bir adet konu başlğ̆ında yer alan temalarla ilişkilendirilmiştir. Elde edilen bulgular netice olarak farklı kültürel deneyimler yaşayan toplumlarda aile kurumunun sürdürülebilirliğine ilişkin "yaşantı" biçimlerinin varlık gösterdiği ve gündelik yaşam zorluklarıyla mücadele alanlarının farklı "baş etme stratejileri" ile yoğunlukta olduğu gözlenmektedir. Böylece, her ne kadar farklı toplumların tarihsel ve toplumsal dünyada yaşantı biçimleri farklılaşsa da söz konusu aile kurumu olduğunda, bu konuda kültürel benzerliklerin biraradalığının ve etkileşimin görünür olduğunu söylemek mümkün olmaktadır.

\section{Yöntem}

Bu çalışma, nitel araştırma yöntemleri kullanılarak yapılmaktadır. Nitel araştırmalarda görsel materyallerden yararlanılarak belge analizi yapılabilmektedir (Mayring, 2011, s.52). İletişim araçları sinema, TV, video, afişler, poster, fotograf ve benzeri olarak iletişim dünyasındaki ve günlük hayattaki yeri genişledikçe bu araçların sosyolojik incelenmesi ve değerlendirilmesine yönelik ihtiyaç doğmaktadır (Bilgin, 2006, s.161).

Görsel araştırmalarda görüntüler, elde edildikleri kaynağa göre iki büyük alan içerisinde değerlendirilmektedir. İlki; üretilmiş, hazır ya da buluntu görsellerdir. İkincisi ise araştırmacıların saha çalışmalarında kendilerinin ürettiği görsel malzemelerdir. Toplumların üretmiş oldukları buluntu ya da hazır görüntüleri inceleme nesnesi olarak ele alan araştırmalar, görsel sosyolojik araştırmaların önemli bir bölümünü oluşturmaktadır (Toksoy, 2019). Çalışmada herhangi bir sınırlandırmaya gidilmemiş ve buluntu veya hazır görüntüleri inceleme nesnesi olarak TRTBELGESEL'de yayımlanan "Aile olmak" adlı belgesel analiz edilmiştir. Bulgular, belgeselde her biri ayrı ayrı konularla ele alınarak işlenen on bir bölümlük videonun tamamını kapsayan verilerden elde edilmiştir. Sonrasında, görsel materyaller eşliğinde veriler, öncelikle gruplara ayrılarak kategorize edilmiş sonrasında ise anlamlandırılmış, betimlenmiş, yorumlanmış ve değerlendirilmiştir.

\section{Bulgular}

Çalışmanın bulgularında, TRTBELGESEL'de yayınlanan "Aile Olmak" adlı on bir adet belgesel serisinden elde edilen verilerin bulguları yer almaktadır. 
Belgeselde birbirinden farklı ülkelerde yaşayan insanların aile yaşamına dair deneyimleri, içinde yaşadığımız topluma bir farkındalık sunması açısından oldukça anlamlı bulunmaktadır. Sembolik açıdan "aile olmak" adlı belgeselde hem görsel hem de işitsel açıdan farklı kültürlerde yaşayan toplumların aile "yaşantı" biçimlerine dair adeta göstergeler şöleni sunulmaktadır. Belgesel serisinin içeriğine gelince gündelik yaşamda sokaktan küresel süreçlere kadar etkilendikleri tüm toplumsal, ekonomik ve tarihsel süreçleri göstergeler aracılı̆̆ıla anlamlandırmak, betimlemek, yorumlamak ve değerlendirmek mümkün olmaktadır.

\section{Demografik Bulgular}

Çalışmanın birinci konusunu oluşturan Yeni Kahramanlar, "gurbetçi"; ikinci konusunu oluşturan Zeytin Ağaçlarmın Altında, Mülteci, "Mekân, Engellilik, Travma, Sağlık-Yetersiz Beslenme"; üçüncü konusunu oluşturan Rüyaların Peşinde; “Niteliksiz İşgücü”; dördüncü konusunu oluşturan “Çölün Başladı̆̆ Yer", "Yerleşim-Ulaşım, Kuraklık, Tarım-Hayvancılık, Yerleşim-Ulaşım, Sağlık-Yaşlılık, Zanaat-Sermaye, Eğitim/Fırsat Eşitsizliği"; beşinci konusunu oluşturan Şehrin Son Sakinleri, “Savaş, Göç, İletişim”; altınc konusunu oluşturan İyi Tatiller, “Emperyalizm, Turizm, Kültürel Yozlaşma, Değerler, Eşitsizlik"; yedinci konusunu oluşturan Su Üstünde İki Hikâye, "Balık Besiciliği, Kapitalizm, Gündelik Yaşam"; sekizinci konusunu oluşturan Çöl Yolcuları, "Çocukluk", dokuzuncu konusunu oluşturan Bozkırm Bekçileri, "Göçebelik, Kent, Gelenekler"; onuncu konusunu oluşturan Beklenen Gün, "İşgal, Yoksulluk, Sömürü"; on birinci konusunu oluşturan Büyük Dua, "Çocuk Hizmetleri, Darbe-Tarih, Haberleşme/Mektup, Duygular-Dil”" ana temalarını içermektedir. 
Tablo 1. “Aile Olmak” (TRTBELGESEL) Demografik Bilgiler/Tanıtıcı Özellikler

\begin{tabular}{|c|c|c|c|c|c|}
\hline Bölüm/Süre & Konu & Karakter & Yer & Ana Tema & Yönetmen \\
\hline 1 (25dk.06sn) & $\begin{array}{l}\text { Yeni } \\
\text { Kahramanlar }\end{array}$ & Beny & $\begin{array}{l}\text { Filipinler/ Banaue } \\
\text { Pirinç Terasları } \\
\end{array}$ & Gurbetçi & \\
\hline 2 (24dk.32 sn.) & $\begin{array}{l}\text { Zeytin } \\
\text { Ağaçlarının } \\
\text { Altında } \\
\end{array}$ & Fida & Suriye & $\begin{array}{l}\text { Mülteci, Mekân, Engellilik, } \\
\text { Travma, Sağlık- } \\
\text { Yetersiz Beslenme }\end{array}$ & \\
\hline 3 (25dk.02 sn.) & $\begin{array}{l}\text { Rüyaların } \\
\text { Peşinde }\end{array}$ & Amani & $\begin{array}{l}\text { Zanzibar Takım } \\
\text { Adaları/Buzi Adası }\end{array}$ & Niteliksiz İsgücü & \\
\hline 4 (24dk.34sn.) & $\begin{array}{l}\text { Çölün } \\
\text { Başladığı } \\
\text { Yer }\end{array}$ & $\begin{array}{l}\text { Ümeyme- } \\
\text { Hafız }\end{array}$ & Moritanya & $\begin{array}{l}\text { Yerleşim-Ulaşım, Kuraklık, } \\
\text { Tarım-Hayvancllı, Yerleşim, } \\
\text { Ulaşım, Sağlık-Yaşlılık, } \\
\text { Zanaat-Sermaye, } \\
\text { Eğitim/Fırsat Eşitsizliği }\end{array}$ & 5 \\
\hline 5 (23dk.02sn.) & $\begin{array}{l}\text { Şehrin Son } \\
\text { Sakinleri }\end{array}$ & Rucva & Suriye & Savaş, Göç, İletişim & 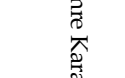 \\
\hline 6 (25dk.00sn.) & İyi Tatiller & Cuma & Zanzibar & $\begin{array}{l}\text { Emperyalizm, Turizm, Kültürel } \\
\text { Yozlaşma, Değerler, Eşitsizlik }\end{array}$ & 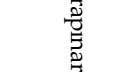 \\
\hline 7 (27dk.03sn.) & $\begin{array}{l}\text { Su Üstünde } \\
\text { İki Hikâye }\end{array}$ & $\begin{array}{l}\text { Abdurrauf ve } \\
\text { Murayda }\end{array}$ & $\begin{array}{l}\text { Filipinler/ } \\
\text { Mindenao }\end{array}$ & $\begin{array}{l}\text { Balık Besiciliği, Kayıkçılık, } \\
\text { Kapitalizm, Gündelik Yaşam }\end{array}$ & \\
\hline 8 (26dk.19sn.) & Çöl Yolcuları & $\begin{array}{l}\text { İbrahim ve } \\
\text { Yahya }\end{array}$ & Çad Çölleri & Çocukluk & \\
\hline 9 (24dk.01sn.) & $\begin{array}{l}\text { Bozkırın } \\
\text { Bekçileri }\end{array}$ & Berdihat & Moğolistan & Göçebelik, Kent, Gelenekler & \\
\hline 10 (23dk.33sn.) & $\begin{array}{l}\text { Beklenen } \\
\text { Gün }\end{array}$ & Azizullah & Afganistan & İşgal, Yoksulluk, Sömürü & \\
\hline 11 (27dk.06sn.) & $\begin{array}{l}\text { Büyük } \\
\text { Dua }\end{array}$ & $\begin{array}{l}\text { Gina ve } \\
\text { Alpaslan }\end{array}$ & $\begin{array}{l}\text { Endonezya/ } \\
\text { Türkiye }\end{array}$ & $\begin{array}{l}\text { Çocuk Hizmetleri, Darbe-Tarih, } \\
\text { Haberleşme/Mektup } \\
\text { Duygular-Dil }\end{array}$ & \\
\hline
\end{tabular}

Kaynak: TRTBELGESEL, 2019, https://www.trtbelgesel.com.tr/kultur-antropoloji/aile-olmak

"Bütün yıkıcı unsurlara rağmen, aile kurumunu ayakta tutmak için mücadele eden annelerin, babalarn ve çocukların etkileyici hikâyesi...her bir bölümde yeryüzünün farklı bölgelerinde yaşayan; birbirinden farklı insan hikâyelerini evlerimize, bizim ailelerimize konuk ediyor" (TRTBELGESEL, 2019).

Belgeselin tümünü kapsayan yukarıdaki ifade, aile kurumuna yönelik tehditlere karşı inşa edilen "baş etme stratejileri”nin tarihsel ve toplumsal dünyanın "yaşantı" alanındaki mücadelelerde, nasıl ve ne şekilde olduğunun sergilenmesi ve bunların tümüne ışık tutması açısından dikkat çekicidir.

\section{Bölümler, Ana Temalar ve Görsel Materyaller}

Yeni Kahramanlar (Bölüm 1): Yeni Kahramanlar konusunun anlatıldığ bölüm, "gurbetçi" ana teması üzerinden şekillenmektedir. Bu bölümde doğrudan "göç" olgusundan ziyade "mevsimlik göç" olgusu ele alınmaktadır. Aileler ekonomik anlamda gündelik yaşamlarını idame ettirebilmek için kısa 
ve aralıklı sürelerle coğrafi hareketlilik deneyimi yaşamaktadırlar. Bu durum, aile içi etkileşim ve ilişkileri doğrudan etkileyeceğinden aile kurumuna yönelik bir tehdit olarak görülmektedir.

En çok işçi göçü alma özelliğine sahip ülke olan Filipinler'de yabancı işçi olarak çalışan Beny ve eşinin, “gurbetçi yaşantısını ve kırsal yaşam koşullarının zorlukları"nı anlatmaktadır. Beny yaşamını, Filipinler'in kuzeyinde iki bin yıllık Banaue pirinç teraslarında geçimini sağlayarak geçirmektedir ve ekonomik olarak geçim sıkıntısı yaşamaktadır. Ayrıca Beny tek çocuğu Bensey ile bir kulübe evde yaşamaktadır. Buradaki yaşam öyküsünün altında yatan toplumsal gerçekliğin temelini "ekonomi" ve "aile" arasındaki ilişkisel ağlar belirlemektedir. İki toplumsal alt sistemin birbiriyle olan ilişkisinde aile olgusunun toplumsal gerçekliğinin inşası, karakterlerin insan-doğa mücadelesinde sarf ettikleri enerji ile görünür kılınmaktadır.

"Dağların, tepelerin ve yabani ormanlarm ardındaki bu köy, şehre çok uzak. Telefonun çekmediği araçların geçmediği bu köye ulaşmak kolay değil. Patika yollar, ormanın içinden ve tepelerden geçerek köye ulaşır. Medeniyetin uză̆ına saklanmış insanların hayatı çoğunlukla bu topraklarda geçer" (1. Bölüm, 4.05).

"Milyonlarca çocuk, annesinden veya babasindan bazen da her ikisinden ayrn yaşamak zorunda. Daha konforlu bir yaşam için tercih edilen bu gurbet, aile yapısın zedeliyor. Böyle durumlarda çocuklar, genellikle aile büyükleriyle yaşıyor. Uzaklarda çalışan ebeveynleriyle telefonla veya internet yoluyla haberleşiyorlar" (1. Bölüm, 11.21). 

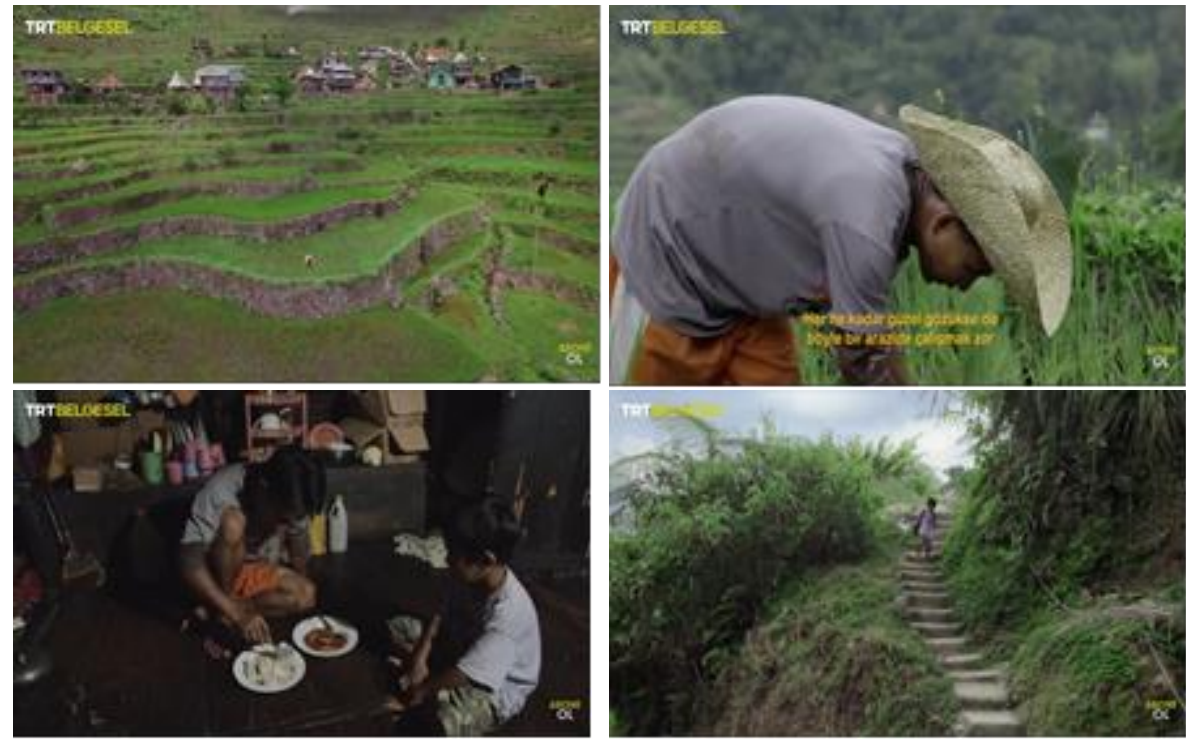

Şekil 1. Yeni Kahramanlar

Bu bölümde, "mesafe" kavramının beraberinde getireceği "duygusal doyum"un özellikle çocuk(lar) açısından manevi/içsel boyutta bir etken oluşturacağını belirtmekte fayda bulunmaktadır. Burada, ekonomik koşulların yoksunluğu sonucunda ortaya çıkan "yoksulluk" ile birlikte tek ebeveyn olarak bir aile yaşamının nasıl ve ne şekilde inşa edildiğini görmek mümkündür. Her ne kadar dezavantajlı koşullar sebebiyle birbirinden uzak kalmak zorunda olan ebeveynler ve çocukları arasındaki bağda "mesafe" engeli ile karşılaşılsa da aralarındaki "iletişim ağları" ve "etkileşim" devam etmektedir.

Zeytin Ağaçlarnnın Altında (Bölüm 2): Zeytin Ağaçlarının Altında başlıklı ikinci bölümde, "mekân, engellilik, travma, sağlıksiz-yetersiz beslenme" ana temaları üzerinde durulmaktadır. Bu ana temaların her birinin toplandığı merkez ise "göç" olgusu olmaktadır. Bu bölümde anlatılan göç şekli, küresel çapta yaşanan savaş mağdurlarının "yaşantı" larının yansımalarıdır. Eğer bir yerde bir savaştan bahsediliyorsa orada yıkımın, afetlerin, çöküntülerin, karmaşanın, kaosun yaşanmaması mümkün değildir. İkinci bölümün anlatıldığı kısımda, mülteci kamplarına konumlanmak zorunda kalmış insanların, bu kamplarda gündelik yaşamlarını yeniden inşa etme stratejileri gösterilmektedir. Belgesel'de en dikkat çekici nokta kuşkusuz "bu kampta yaşayan her çocuk yetim, her kadın da dul" bilgisinin yer almasıdır. 
“Burası Suriye'nin Türkiye sinırında bulunan Kerame Mülteci kampı. Şehirler sürekli bombalanırken zeytinlikler hayata tutunmanın adresi oldu. Savaştan kaçanlar, önce zeytin ă̆alarının gölgesine sı̆̆ındı. Sonra da kendi imkânlarıla geçici çadırlar inşa ettiler. Yakın zamanda evlerine döneceklerdi. Ancak hiçbir zaman evlerine dönemediler. Savaş uzun yıllar sürdü. Çadırlar giderek çoğaldı ve burada yeni bir hayat başladı" (2. Bölüm, 2.10).

Bu kamplarda toplumsal gerçeklik, Berger ve Luckmann'ın (2008) tespit ettiği gibi "şimdi" ve "burada"dır. Bölümün ana karakteri olan Fida, savaşın mağdurlarından sadece biridir. Savaşta bir bacağını kaybetmiş olsa da başka mağdurların yaralarını sarmak için destek olmaya çalışmaktadır.
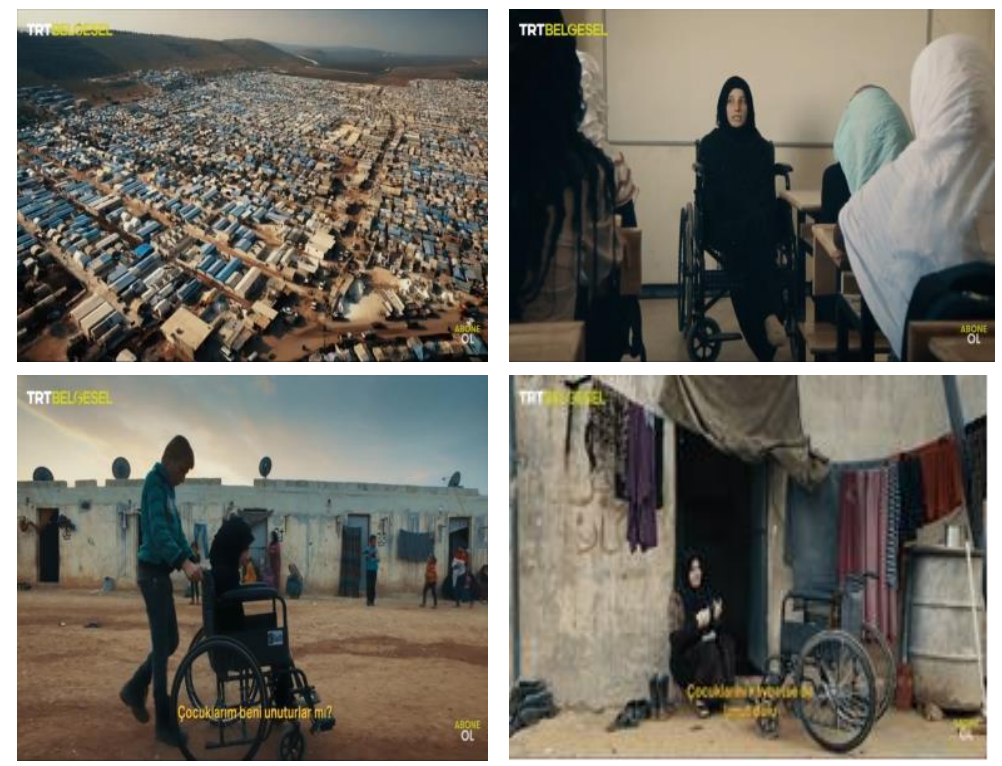

Şekil 2. Zeytin Ağaçlarının Altında

Yaklaşık elli bin kişinin yaşadığı bu kampta gönüllü öğretmenlik yapan Fida, travma yaşayan çocukların toplumsal hayata kazandırılması çabasındadır. Bu kısım, Fida'nın dezavantajlı durumunu kendini yeniden inşa etmesi yönünden bir fırsat fakat çocuklarından fiziksel ve duygusal açıdan ayrı olması sebebiyle aileye yönelik bir tehdit olarak değerlendirilebilir (Demir, 2020, s.265).

“Fida'nın yaraları çok taze. Bacağını kaybetmesinin üzerinden henüz yedi ay geçmesine rağmen okula gidip gelirken zorlanyyor. Tekerlekli sandalyeye mahkûm olsa 
da onu hayata bağlayan bir şey var. Çocuklarına kavuşacak olma umuduyla yaşıyor" (2. Bölüm, 7.38).

Esasında, yaşadığı yeri terk etmek zorunda kalan her çocuğun anlatıldığı bu yaşam öyküsünde eğitim, toplumsal yaşamın devamlılı̆̆ını sağlayan ve bireylerin yaşama tutunmasını kolaylaştıran bir "fırsatlar" silsilesi olarak sunulmaktadır. Mülteci bir yaşamın beraberinde getirdiği sosyo-ekonomik zorluklar özellikle de yoksulluk ve yetersiz beslenme sebebiyle kamplarda yaşayan bireylerin sağlıklarını olumsuz yönde etkilemektedir. Elbette sağlık konusundan bahsediliyorsa, mülteci kamplarındaki sağlık hizmetlerinin ve uluslararası yardım kuruluşlarının ve buna benzer yapılanmaların durumu önemli olmaktadır. Çünkü bu konuya ilişkin ne şekilde ve nasıl önlemler alınarak müdahale edildiği ve iyileştirme faaliyetlerinin neler olduğu kuşkusuz önem taşımaktadır.

Rüyalarn Peşinde (Bölüm 3): Rüyaların Peşinde bölümünün ana karakteri Amani'dir. Bölüm içerik olarak Zanzibar Takım Adaları'nda yaşayan ve gelecekte doktor olmak isteyen fakat yaşadığı adada okul olmadığı için her gün başka bir adaya geçiş yapmak zorunda olan bir karakterin (Amani) gündelik yaşamını konu edinmektedir.
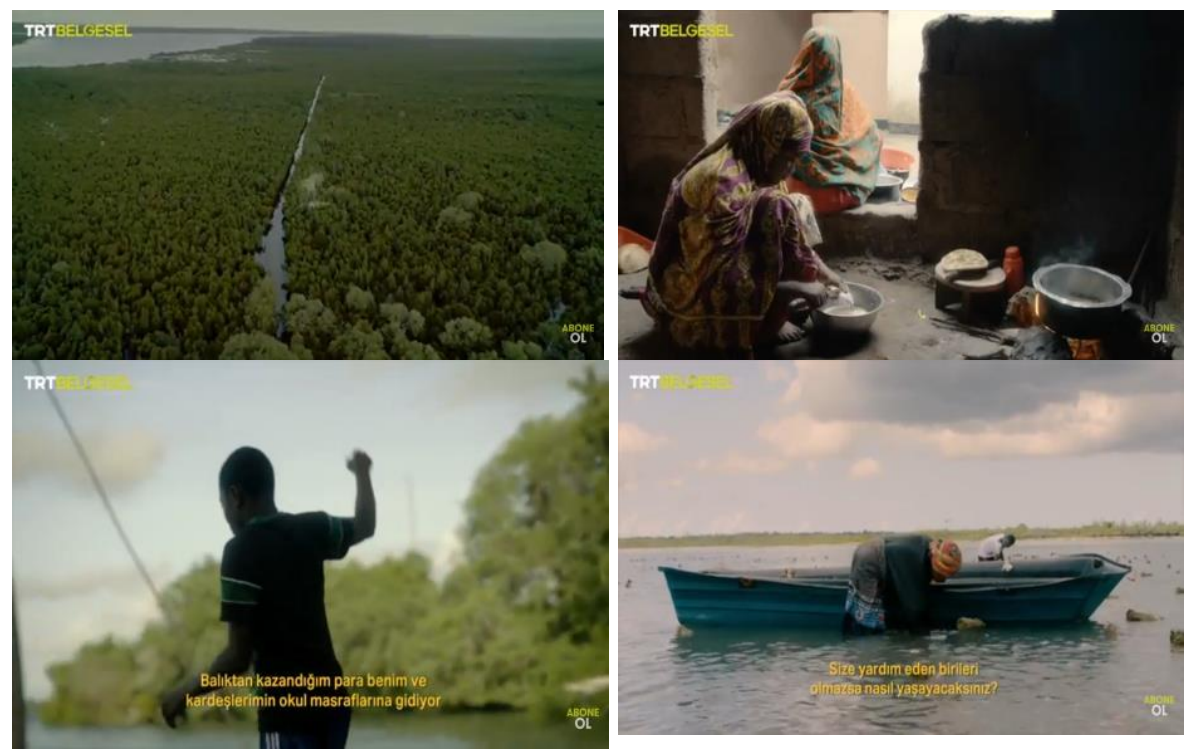

Şekil 3. Rüyalarn Peşinde 
“Bu küçük ve gizemli adada hayat, ormanm içinde mango ve muz ă̆açlarnmn arasında kurulu. Tabiatın bahşettiği onlarca nimet olsa da elektrikleri, su şebekeleri, yolları, okulları ve elbette hastaneleri yok. Medeniyetin uză̆ında yaşayan bölge halkı çalışmak için diğer adalara gitmek zorunda kalıyor veya burada balıkçılık ile ilgileniyor" (3. Bölüm, 5.44).

Amani hem okula gitmek hem de annesi ve beş kardeşten oluşan ailesine bakmak zorundadır. Bu yüzden, ailesine ekonomik olarak katkı sunmak amacıyla gündelik hayatında arta kalan zamanlarında balıkçılık işlerinde çalışmak zorunda kalmaktadır. Böylece, bölümün ana temasını şekillendiren "niteliksiz işgücü" sorunu belirlenmektedir. Bu durum aynı zamanda toplumsal bir gerçeklik olan niteliksiz iş gücünün beraberinde getirdiği "çocuk işçiler" meselesini de günyüzüne çıkarmaktadır.

“Akşamın karanlığı aileyi sofraya çă̆ırırken evlerde yemekler pişer. Yokluğun ortasinda bile leziz yemekler yapmak, annelerin marifetidir. Buradaki evlerin çoğunda aynı manzarayı görmek mümkündür. Modern ocaklar, firınlar, buzdolapları ve koltuklar olmasa da bir sofranın etrafinda buluşmanın tadı dünyanın her yerinde ayndır" (3. Bölüm, 20.16).

Bu farkl1 kültürlerde modernleşmenin, sanayileşmenin bir fiil görülmeyen gündelik yaşam deneyimleri, bize Berger ve Luckmann'ın (2008), kuramlarında belirttikleri “öteki” lerden uzak bir dünyayı resmetmektedir. Aile temelindeki geleneksel örüntülerin, yoksulluk ağında devamlılığını sürdürmesi yine bu bölümün baskın öğelerinden birisi olarak görülmektedir. Amani, gündelik yaşamın tüm zorluklarına rağmen eğitim ve kariyer açısından rüyalarının peşinde koşmaktan vazgeçmeyen ve sosyal değerlerden biri olarak inşa edilen aile olmanın farkındalığına sahip bir karakter olarak sunulmaktadir.

Çölün Başladı̆̆ı Yer (Bölüm 4): Çölün Başladığı Yer, yerleşim, ulaşım, kuraklık, tarım, hayvancılık, ulaşım, sağlık, yaşlılık, zanaat, sermaye, eğitim, fırsat eşitsizliği ana temalarının işlendiği dördüncü bölümü içermektedir. Bu bölümde, eşi uzun süredir uzaklarda tedavi gören Humeyme karakterinin, bir anne olarak çöl şartlarında çocukları için verdiği mücadelenin hikayesi anlatılmaktadir.

"Hümeyme, bir süre suya giderken kızın da beraberinde götürüyor. Her anne gibi kızına su yolunu öğretmesi gerek. Kum tepelerinin sürekli yer değiştirdiği bu çölde yol bulmak kolay değil...ve aniden ortaya çıkan kum firtınaları çocuklar için ölümcül 
olabilir. Kızını tek başına suya göndermek konusunda emin değil. Kafasındaysa tüm bunlara çözüm olacak bir plan var. Hümeyme'nin bir evi yok. Akrabalarnm verdiği barakada yaşıyor. Dört çocuğuna ve felçli kayınpederine bakmak zorunda. Çünkü kocası uzun süredir hasta. Tedavi olmak için gittiği şehirden aylarca dönmedi. Moritanya'da sadece 20 hastane var. Ve hastanelerin hepsi büyük şehirlerde. İnsanlar tedavi olmak için yaşadıklar yerden uzaklaşmak zorunda... Bütün yük Hümeyme'nin omuzlarnnda. Ailesini ayakta tutabilmek için çalışmalı. Peki çölün ortasında bir insan ne yapabilir?" (4. Bölüm, 3.31).

$\mathrm{Bu}$ bölümün konusu, tarıma elverişli arazilerin neredeyse olmadığı, kuraklığın hâkim olduğu, ülkenin büyük bölümünde yerleşimin olmaması ve çöllerle kaplı olması, suya ulaşmak için kilometlerce yol gitmek zorunda kalan insanların zahmetli ve eziyetli yaşam koşullarını ortaya çıkaran, Batı Afrika ülkesinin Moritanya Kıtası'nda geçmektedir.
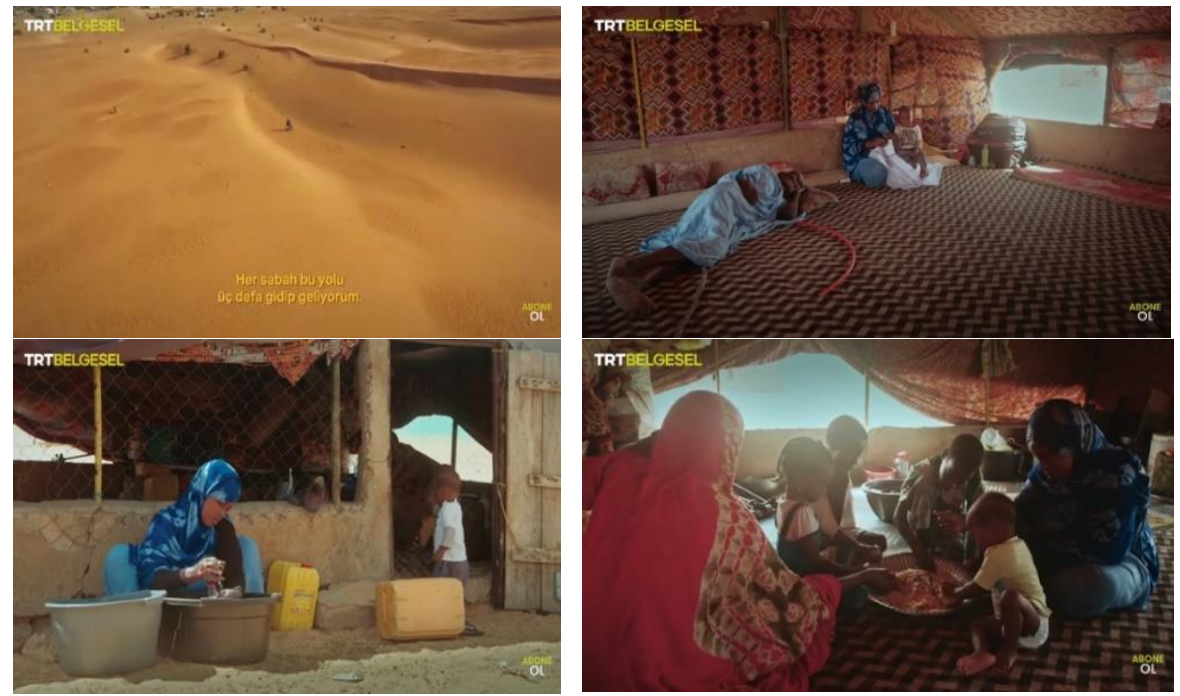

\section{Şekil 4. Çölün Başladığı Yer}

Hümeyme karakteri bu hikayede ekonomik koşulların oldukça zor yaşandığ1 kurak çöllerde kumaşlar üzerine yapılan işlemelerle oluşturduğu "zanaat" ile gündelik yaşamını idame ettirmek zorundadır. Ancak ekonomik sermayenin olmayışı, farklı iş alanlarına yönelmeyi getirmektedir. Bu sebeple, köylerinde yaşayan ve nispeten daha varlıklı ailelerin evlerinde "temizlik hizmetleri" yapmak durumunda kalmaktadır. 
Şehrin Son Sakinleri (Bölüm 5): Şehrin Son Sakinlerinde, Suriye'de bir pazar yerine düşen bomba sonucu kocasını kaybetmiş, ailesini ayakta tutmaya çalışan bir annenin ve çocuklarının hikâyesi anlatılmaktadır.

"Uzun zamandır savaşın hüküm sürdüğ̈̈ Suriye topraklar, baskıcı rejimin katliamlarıyla başlayan çatışmalar bir iç savaşa dönüştü. Şehirlerin birçoğu bombalandı ve yirmi milyonluk Suriye nüfusu giderek azald. Yüzbinlerce kişi öldü ve milyonlarca kişi yaşadığı yeri terk etmek zorunda kaldı. Birçok ülke farklı sebeplerle çatışmalara katıldı (5. Bölüm, 2.52). Her gün yüzlerce sivil bu saldırlarda katlediliyor. Ancak gökyüzünden bomba yağdıran bu ittifakın öldüremediği insanlar hala var ve harabeye uğ ramış şehirlerde yaşamaya ediyorlar. Bombalarm rastgele düştüğ̈̈ bir yerde güvenle yaşamak mümkün değil. Bir varil bombasının evinizi yerle bir etmesi için herhangi bir sebebe ihtiyacı yok. Zaten bu bombalar çoğu zaman sivilleri öldürür. Suriye'de geceler daha zor geçer. Uçak ve bomba gürültüleri gecenin sessizliğini işgal etmiştir. Ancak hiçbir şey çocuklarm hayallerini esir alamaz" (5. Bölüm, 3.39).

Suriye'de savaşın tam ortasında yaşanan bu hikayedeki ana temalar, savaş, göç ve iletişim olarak belirlenmektedir. Bu kısımda aile yaşamına dair en can alıcı nokta, "gecenin sessizliği"nin yerine, gündelik yaşamda toplumsal gerçekliğin "karanlığın işgali" üzerine inşa edilmesidir.

"Rucva, artık bu çorapları (kocasının) görmek istemiyor. O günü hatırlamak istemiyor. O kocasını kaybetti ben de kardeşimi. Rucva'nın eşi benim küçük kardeşimdi. Pazarda çorap satarken hayatıı kaybetti. Varil bombası Pazar yerinin ortasına düştü. O gün çok sayıda insan öldü. Geriye bu kanlı çoraplardan başka hiçbir şey bırakmadı. Ve altı tane yetim çocuk. Hayat çocuklar için çok daha zor. Ama hala hayalleri var. Hala okumak istiyorlar. Mesela bazen benden kitap istiyorlar. Viam okulunu tamamlamak istiyor ama savaş devam ettiği sürece bu çok zor. Burada okullar bile bombalanıyor. Çocuklara bile acımıyorlar. Hiç kimseye acımıyorlar" (Rucva'nın kayınbiraderi, 5. Bölüm, 15.05). 

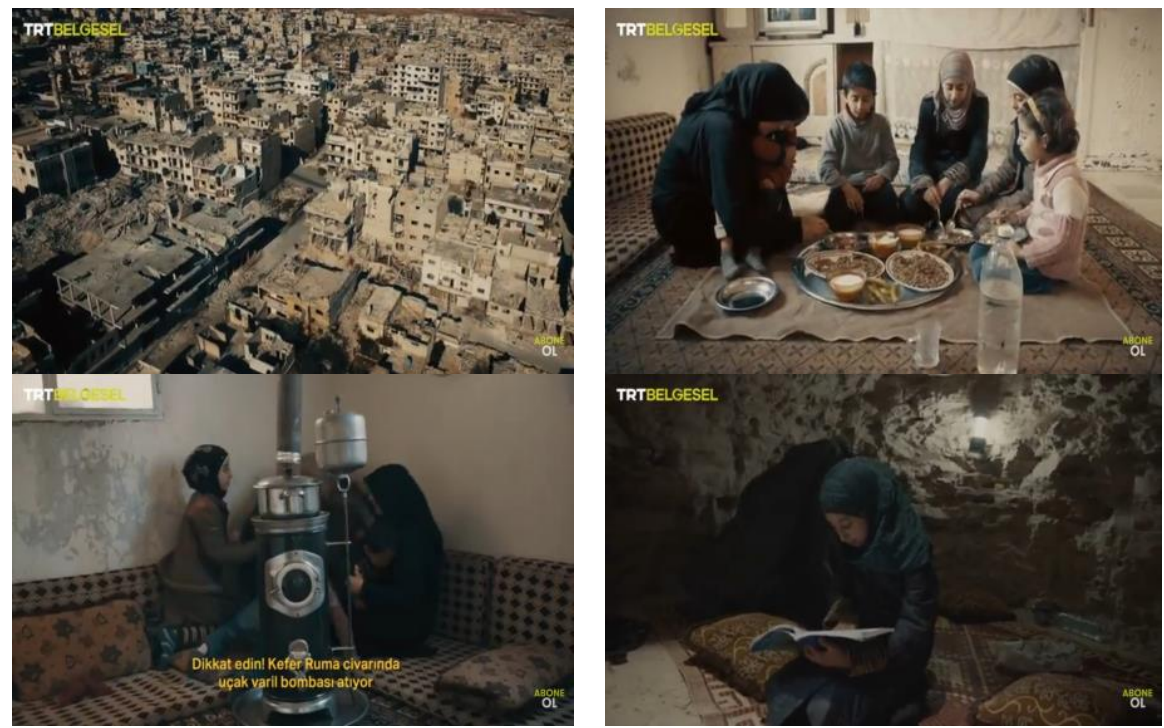

Şekil 5. Şehrin Son Sakinleri

Şehrin Son Sakinleri isimli bu bölümde, savaş mağduru olan fakat göç etmemiş, gündelik yaşamlarını çatışma ortamında sürdürmeye çalışan insanların yaşantıları anlatılmaktadır. Suriye, konjonktürel açıdan uluslararası güçler tarafından çevrelenmiş stratejik bir savaş arenasının olduğu yerdir. Dolayısıyla burada insanların gündelik yaşamları öncelikle hayatta kalabilme ve barınma gibi temel ihtiyaçlar üzerinde biçimlenmektedir.

Uluslararası perspektifte, emperyalizmin her zerresinin hissedildiği bir alan gözler önüne serilmektedir. Burada, az gelişmişliğin tüm boyutlarını deneyimleyen insanlarla karşılaşmak mümkündür. Çatışmanın hâkim olduğu bu yerlerde, aile temelinde toplumsal düzen ve uyumun devamlıllğ 1 için bir nebze çaba gösterilmektedir. Her ne kadar aile olmaya yönelik bu dezavantajlı durumlar bir tehdit unsuru olarak belirse de Rucva ve ailesi bu değerleri "samimiyet" duygusu içerisinde korumaya devam etmektedir.

İyi Tatiller (Bölüm 6): İyi tatiller konusunun anlatıldığı altıncı bölümde, medresede gönüllü hocalık yapan Cuma'nın kendi yaşamını inşa etmek için verdiği mücadelenin hikâyesi anlatılmaktadır. Bu bölümün konusu, Zanzibar takımadalarında geçmektedir. 

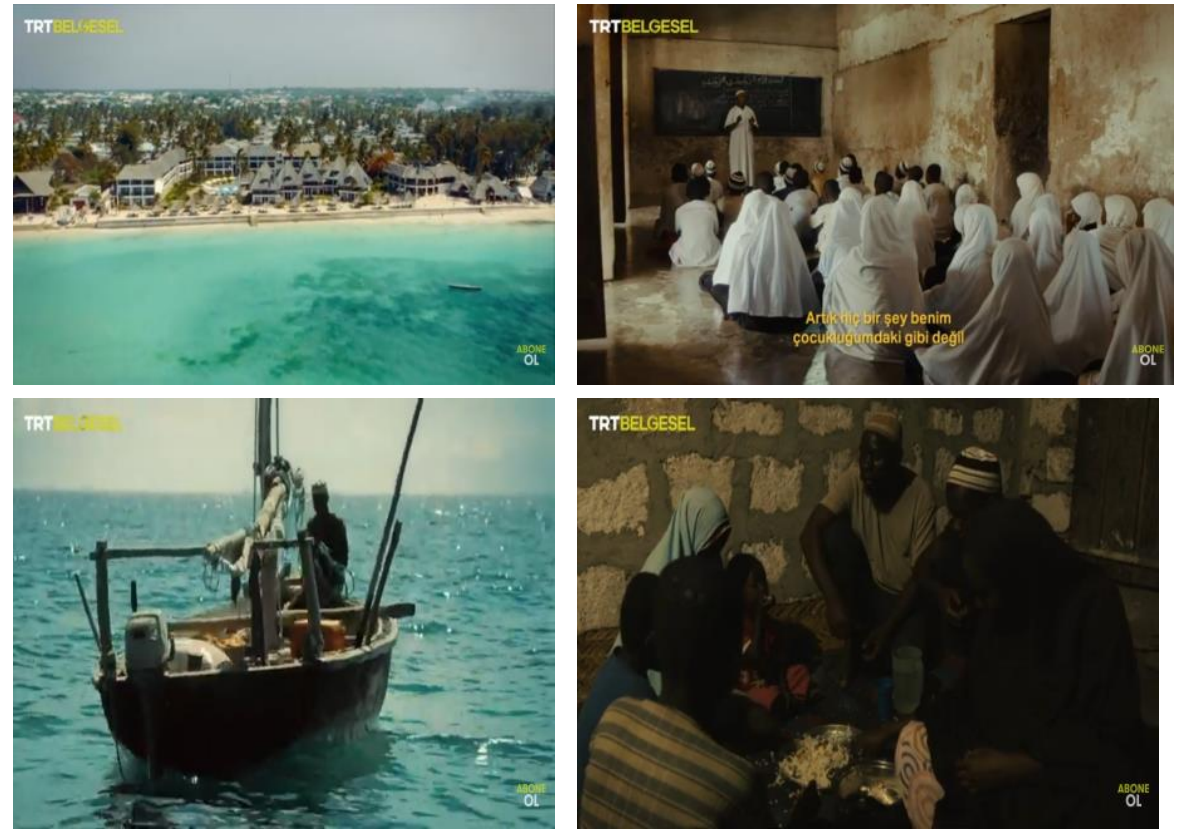

Şekil 6. İyi Tatiller

"Zanzibar, şimdilerde dünyanın dikkat çeken turistik yerlerinde birisi. Uçsuz bucaksız turkuaz sahilleri her yıl binlerce turist ă̆ırlıyor. Ilk başlarda yerli halk turizmin adaya zenginlik getireceğini düşünmüsstü. Çok geçmeden öyle olduğunu anladılar. Artık turizmin sebep olduğu ahlaki yozlaşmayla uğraşmak zorundaydılar. Bu problemin üstesinden gelmeye çalışan, kendini vatanına borçlu görenlerden biri de yirmi beş yaşındaki Cuma. Hem çalışıyor hem de gönüllü hocalık yapıyor. Çalışmadığı zamanlarda vaktini bölgenin çocuklarıyla geçiriyor" (6. Bölüm, 2.41).

Ailede değerler, orta ölçekli bir konu olan "ev yönetimi"nin bir parçasını oluşturmaktadır. Evlilik değerleri, terbiye değerleri, geçim değerleri, sayg1 değerleri ve görgü değerleri aile konusuna ilişkin değerler olarak sıralanabilir (Canatan, 2013, s.288-290). Bu bölümde, emperyalizm kıskacı altında yaşayan insanların kendi kültürel ve sosyal değerlerini koruma çabası, Zanzibar adasındaki yaşantının bir göstergesi olmaktadır. Cuma, yozlaşma sebebiyle tahribata uğradığına inanılan değerlerin korunması ve sürdürülmesi gerektiğine inanan ve kendisini bu amaca adayan idealist bir karakter olarak sunulmaktadir. 
"İdeallerin, değerlerin ve çocuk civultılarmn arasından kimsenin bilmediğ̀i uzaklara bir yol olduğunu kim bilebilir. Sakince oturup geleceği hayal eden birinin aklndan neler geçer. Mahallenin hemen dışına gürülttünün uză̆ına, buraya onu çeken şey nedir? Cuma'nın hayalleri sinırsız olsa da yakında gerçekleşecek şeyi bekliyor. Arada sırada buraya gelip (ağacın altı) geçmişi ve geleceği düşünüyor. Günler geçip giderken yapabileceği tek şey sabırla mücadele etmek (6. Bölüm, 5.03). Zorlu koşullar, geleneksel avcıların engelli kalmasıyla sonuçlanıyor. Zanzibar'lı balıkçlar için hayat hep zor geçiyor. Kendi tutukları bahklar pahah olduğu için otellere ve lokantalara gitmiştir. Yoksul halkm sofrasın ise pirinç ve daha küçük balıklar şenlendirir. Yoklukta bile sofrayı lezzetli hale getirmek maharet gerektirir. Buradaki evlerin çoğunda aymı manzarayı görmek mümkündür. Birkaç parça eşyadan fazlası yoktur. Gazlı ocaklar, elektrikli firmlar olmasa da yemek yapmak için illaki bir yol bulunur. Akşamın karanlığı aileyi sofraya davet eden bir çă̆rıdır. Bin yıllardır bu çağrı, belli belirsiz bir dürtüyle insanlarn evine götürür. Bu ev bazllarnna eksik ve yaşanılamaz gelebilir. Bu sofra bazılarna yeterli görünmeyebilir. Peki huzurla dolu bir evin noksan olduğunu kim iddia edebilir?" (6. Bölüm, 17.33).

Yukarıda anlatılanlarda görüldüğü gibi, “turizm” ile özdeşleşen bir adada yaşayan yerli halkın gündelik hayat koşulları "yoksulluk" derecesinde yaşanmaktadır. Fakat her ne kadar bu zorlu koşullar bir tehdit unsuru olarak karşılarına çıksa da duygusal ilişkilerle bir araya geldikleri aile ortamında bu yoksulluk izleri bertaraf edilebilmektedir. Gündelik yaşam koşullarının zorlukları, mücadele ekseninde birleşerek bir etkileşim ağı oluşturmakta ve ailenin birbirine tutunma biçiminde parçalanmalara ya da yok olmalara sebebiyet vermemektedir.

Su Üstünde İki Hikâyesi (Bölüm 7): Su Üstünde İki Hikâyesi; balık besiciliği, kayıkçılık, kapitalizm ve gündelik yaşam üçgeninde geçen bir yaşamın hikâyesinin anlatıldığ 1 yedinci bölümü oluşturmaktadır. Bu bölümde, ailesinden uzakta, gölde balık besiciliği yapan Abdurrauf'un ve bir yandan çalışıp bir yandan da okumak zorunda olan Murayda'nın hikâyesi anlatılmaktadir. 

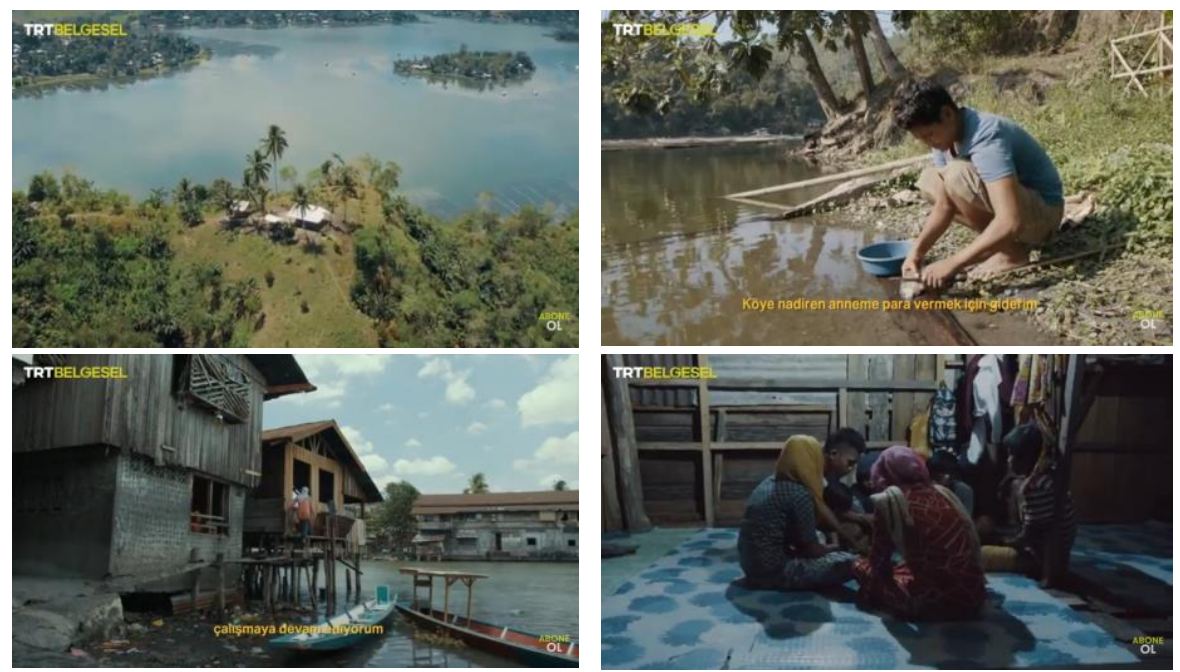

Şekil 7. Su Üstünde İki Hikâyesi

“Dağın içinden kaynayan su, yüzyıllardır hem insanları hem de gölü besler. Ancak bölge sakinleri içme suyuna ulaşabilmek için gölün kaynağına gitmek zorundadır. Metropollerde sinırsizca tüketilirken dünyanın büyük bölümünde su için yolculuk yapmak hayatın bir parçasıdır. Abdurrauf ve arkadaşı iki günde bir bu zorlu yolculuğa çıkar. Ve bu yolculuğu eğlenceli hale getirmenin mutlaka bir yolunu bulurlar. Üstünde yaşadtğımız gezegenin en büyük farkıdır su...çocuklar yolculuklarımı tamamladı ancak onları bekleyen bir sürpriz var. Evlerine dönebilmek için kaybolan kayıklarnnın yerine geçici bir çözüm bulmak zorundalar. Çünkü Abdurrrauf'un bir an önce çiftliğine ulaşması gerek. Buldukları çözüm çok da güvenli değil" (7. Bölüm, 09.08).

"Eğer balklarnn başına bir şey gelirse, bunun ücretini benden keserler. Benim ise hem kendi ihtiyaçlarımı karşılamam hem de anneme para götürmem gerekiyor. İki kardeşim var ve onlar daha kü̧̈ükler" (Abdurrauf, 7. Bölüm, 12.57).

Bu bölümdeki en dikkat çekici nokta gündelik yaşama dair, Abdurrauf'un en hareketli gününde dahi hayatın burada yavaş geçmesidir ve yalnız yaşamanın getirdiği zorluklardır. Ailesinden uzakta geçirdiği her gün sonrasında, içsel/duygusal açıdan "özlem" duygusu yaşamaktadır. Bu oldukça zor olan yaşam koşulları, onu yalnız ve uzun günlere mahkûm etmeye devam etmektedir. Murayda'nın hikâyesine gelince, kendi sözleriyle aşağıda şu şekilde aktarılmıştır:

"Her gün güneş doğmadan önce uyanıyorum. Kayığı hazırlyyorum. Sonra annemi çalşstığı lokantaya bırakıyor ve işe çıkıyorum. Benim işim kayıkçılı. İnsanlar 
bir yerden bir yere gitmek istediklerinde onları taşırm. O gün para kazansam da kazanmasam da kayığın sahibine 15 peso ödemek zorundayım. Çünkü bir kayığım yok ve bu kiralı" (Murayda, 7. Bölüm, 15.10).

Kotavato'nın nehir kısmında yaşayanlar için, su hem bir kaynak hem de önemli bir geçim kaynağı olduğundan nehirde aileler kayıkçılık ve balıkçılıkla geçimlerini sağlamaktadır. Yine ailenin neredeyse tüm üyelerinin çalışmak zorunda olduğu ve gündelik yaşam deneyimlerinin aktarıldığı bu bölümde de ekonomik koşulların aile kurumu üzerinde oldukça belirleyici bir faktör olduğu ortaya çıkmaktadır.

Çöl Yolcularn (Bölüm 8): Çöl Yolcularının "göçebe" yaşamlarının sunulduğu sekizinci bölümde; on iki yaşında olan İbrahim ve kardeşi Yahya'nın çöldeki develeriyle birlikte yaptıkları, günler boyunca süren zorlu yolculuğun hikâyesi anlatılmaktadır ve bu hikâye, Libya sınırına yakın Çad çöllerinde geçmektedir.

"Maçlar oynanırken stadyumlarda, metroya otobüse ya da taksiye binerken iş çıkışı insanlar şehirlerde, sinavlara hazırlanırken gençler kariyer hayaliyle tatil rezervasyonları yapılırken ardı ardına, lokantalar ve kahve dükkânları dolup taşarken hafta sonlar vitrinler süslenip indirim reyonları açıldığında, bütün bunların çok uzağında ıssızlı̆̆ın ortasında çölde bir hikâye başlar. Çöller dünyanın en ıssız ve en zorlu yerleridir. Buna rağmen insanlar çölde yaşamaya devam eder" (8. Bölüm, 2.30).
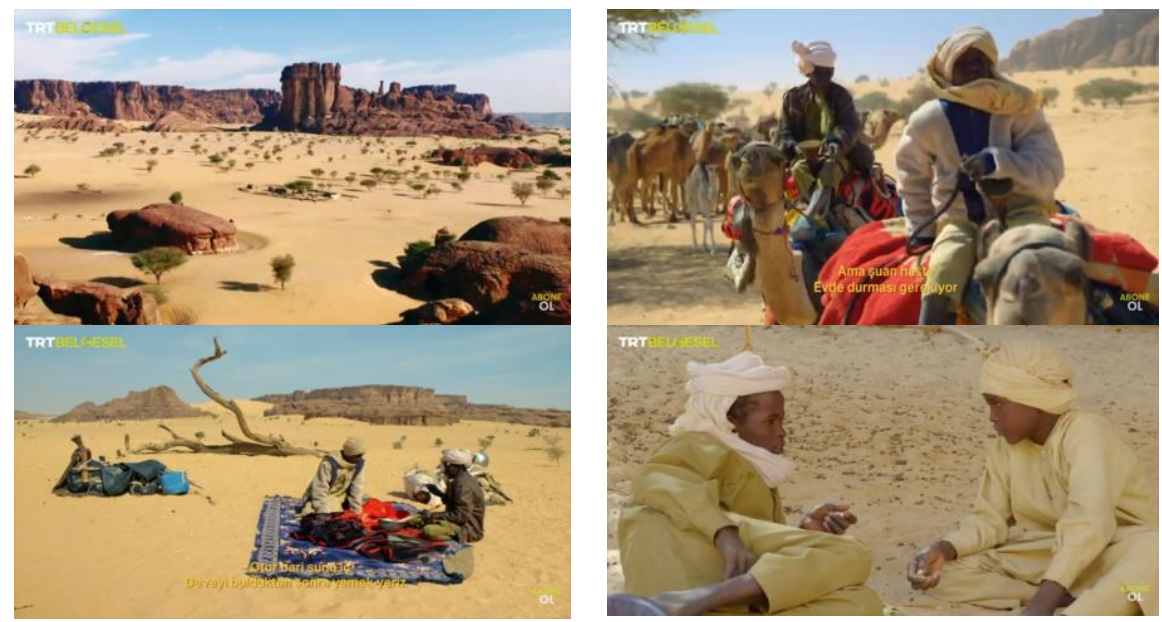

Şekil 8. Çöl Yolcuları 
Burada, çöl yolcularının konu edindiği ana tema olan "çocukluk" olgusunun belirgin bir şekilde ortaya çıktığı görülmektedir. Farklı toplumlarda yaşıtları eğitim hizmetlerinden okullar aracıllğıyla yararlanırken, İbrahim ve Yahya bu durumdan oldukça uzak kalmaktadır. Bu sebeple, "fırsat eşitsizliği" onların içinde bulundukları toplumsal gerçeklik ile belirginlik göstermektedir.

"Dünyanın birçok yerinde çocuklar okula gitmek için hazırlık yapıp erkenden yatarlar. Ancak İbrahim ve Yahya'nn gidebilecekleri bir okul yok. Bu uçsuz ve bucaksiz çöl okulunda erken yaşta büyümek ve kendi başlarının çaresine bakmayı öğrenmek zorundalar. Evlerinden çok uzakta ıssız çölün ortasında onlarn çok uzun bir gece bekliyor" (8. Bölüm, 26.18).

Geleneksel aile yapısı, ekonomik anlamda bir üretim birimi olarak şekillenmektedir. Bu aile yapısında çocuklar, bu üretim biriminin birer parçasıdırlar (Özyurt, 2013, s.170). Bir yandan sosyal ve ekonomik koşulların yetersizliği nedeniyle zorunlu ihtiyaçlarını karşılamak için mücadele ederken, diğer yandan da hayata erken atılmanın verdiği yük ile çocukluk sürecini duygusal doyum noktasında yaşamaktan mahrum olmaktadırlar.

"Çölde yaşayan aileler, gıdaya ulaşabilmek için uzun yolculuklara çıkmak zorunda. Bu onların hayatının sıradan bir parçası (8. Bölüm, 19.34). Burada, yer altı zenginlikleri yüzünden işgale uğramamış hayatları ellerinden alınmamış insanlar yaşardı. Ticaret kervanları uğramasa da her gün binlerce hayvan buraya su için geliyor. Kurtaşi tepelerinin ardından kaynayan su, burada büyük bir nimete dönüşüyor" (8. Bölüm, 20.54).

Yukarıdaki ifadeler, insanların yaşamış olduğu sosyal, ekonomik ve kültürel deneyimlerin toplumdan topluma kültürden kültüre farklılık gösterdiğinin bir örneğini sunmaktadır. Suriye örneğinde olduğu gibi doğrudan işgal anlayışlı emperyalizmin getirdiği toplumsal sonuçlar olmasa da kuraklığın işgal ettiği issız çöllerde geçen zorlu bir yaşantının Çad çöllerinde geçtiğini söylemek mümkündür.

Bozkırnn Bekçileri (Bölüm 9): Bozkırn Bekçileri, Moğolistan'da yaşayan Berdihat ve ailesinin yaşam biçimlerinin anlatıldığı dokuzuncu bölümü oluşturmaktadır. Bu bölümde, ana temalar göçebelik, kent ve gelenekler olmak üzere üç temel üzerine konumlanmaktadır. 

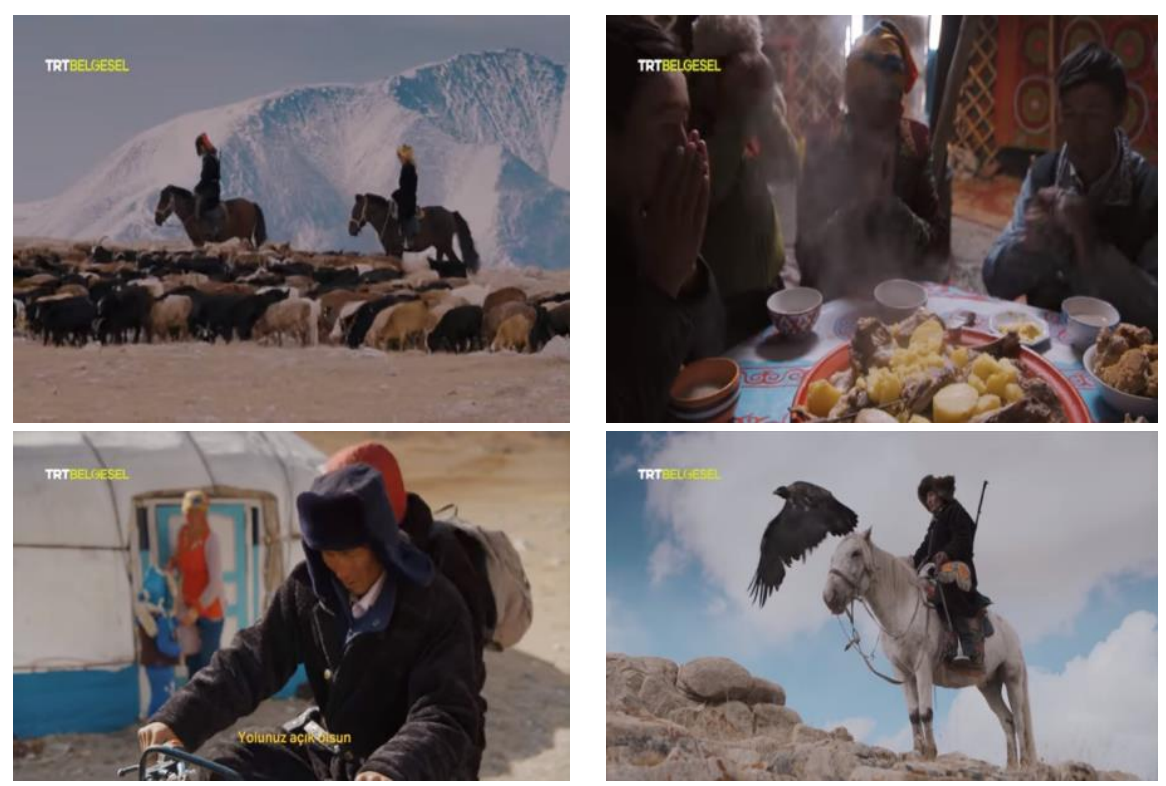

Şekil 9. Bozkırın Bekçileri

"Ben bozkırda doğdum. Babam ve onun babası hep göç yollarında doğdu. Bu topraklarda ovalarda yaşamayı seviyorum. Çocuklarım da seviyor (Berdihat, 3.02). Çocuklarımdan biri okumak için şehre gitti. Ve öğrendim ki hastaymış. Burada olsa bu şifalı otlarla onu hemen iyileştirirdim. Ailemi korumak zorundayım. Hayvanlarımı korumak zorundayım. Hepsi bana Allah'ın emaneti. Bozkırda bir erkek gü̧̈lü olmak zorunda. Burada hayat zor. Ama başka yerde yaşayamam" (Berdihat, 4.17).

Lefebvre'nin (2007) işaret ettiği gibi modern dünyanın üzerine inşa edilen bir toplumsal yaşamdan oldukça farklı kültürel deneyimlerin yaşandığı bozkırda, sınırlı imkanlar doğrultusunda doğayla iç içe yaşayan bir ailenin gündelik yaşantısı anlatılmaktadır. Aile olmanın bozkırda da en temel sosyal değerlerden birisi olduğunu Berdihat'ın yukarıda geçen sözlerinde görmek mümkündür.

"Burada herkesin bir görevi var. Evin küçük oğlu ısınmak için hayvanlarm geride bıraktığı değerli şeyleri topluyor. Evin hanımı ise dünyanın en geniş mutfağında bulaşık makinesini çalıştırıyor. Ankastre ocakta yemekler pişerken uzaktan sürünün ayak sesleri işitiliyor (Metafor-Bozkır/Modernleşme). Yorgunluk, açlık ve biten gün. Bu ıssız bozkırda aileyi bir sofra etrafinda buluşturuyor. Etin en değerli ve en yağgh 
kısımları ise hep ufaklı̆̆ın oluyor. Hava kararıp bozkır akıl almaz soğŭga teslim olurken küçük çadır aile olmanın sıcaklı̆̆ıyla ısınıyor" (9. Bölüm, 5.18).

İş bölümüne dayalı ilişkiler ağıyla örülen aile bağları, kültürel açıdan farklı toplumlarda değişik gibi görünse de burada aile olmanın temelinde yatan esas unsurun, manevi/içsel olarak hissedilen "samimiyet" duygusunda tüm anlamların benzer izler taşıdı̆̆ı söylenebilir.

Beklenen Gün (Bölüm 10): Beklenen Gün'ün konusunun işlendiği onuncu bölümde, işgal yoksulluk ve sömürü ana temaları ele alınmaktadır. Bu belgeselin ana karakteri olan Azizullah'ın işgal sebebiyle oğlunun ölümünden sonra torunu Hatice ile Afganistan'da geçirdiği yaşam hikayesinden bir kesit sunulmaktadir.

"Dünyanın bazı bölgeleri aslında bize gösterilenden farklıdır. Birkaç yüz kilometrede bir ırkların ve kanunlarm değiştiğ i Afganistan topraklarn yeryüzünün en nadide yerlerinden biridir. Tabiat bazı bölgelerde fazlasıyla çetin hayatsa alıştığımızdan farklıdır. Baş edilemez doğası, ulaşılmaz dağları, burada yaşayanların hayatın derinden etkiler. Böylece daime bu topraklar, zorluğa alışkın, özgürlüğ̈̈ne düşkün insanlarnn diyarı olmuştur. Ancak burada yaşayanlar, son iki yüzyılda iki işgale direnmek zorunda kaldı. Sovyetler Birliği ve Amerika işgali sırasında milyonlarca insan öldü. Milyonlarcası da engelli kaldı. İşal günümüzde de devam ediyor ve Afganistan halkı her gün bedel ödüyor. Bu bedeli en ağır ödeyenlerden biri de kimseye zararı olmayan ve kendi halinde yaşayan Azizullah" (10. Bölüm, 2.09).

Berger ve Luckmann (2008)'ın gündelik yaşama ilişkin öne sürdükleri düşüncelerinde "meşrulaştırma" kavramının önemi vurgulanmaktadır. Burada kavramın, Hatice karakterinin çocukluk yıllarının bir kısmını resmi kimliği olmadan sürdürdüğü görülmektedir. Bu durum, modern toplumsal yaşamda bireylerin karşılarına çıkabilecek önemli problem biri olarak algılanır. Çünkü kimlik olmadan kamusal alanda yaşamı idame ettirebilmek mümkün görünmemektedir.

"Dünyanın merkezindeki ateş, kâinatın altı evrede yaratılışı, çamurdan var olan beşer ve hamurun ekmeğe dönüşı̈̈̆̆̈̈ o an. Her şey olup biterken durmadan, daima geçen milyarlarca insan ne çok umut ne çok hüzün ve ne kadar çok yaşam sadece onlardan birisidir hikâyesi anlatılan. Hatice bugün dedesiyle birlikte şehre gidecek. Bu yaşına kadar çıkartamadığı kimliğine kavuşacak. Dede ve torunu birlikte günler geçirecekler. Bu yolculukta birbirlerini daha iyi tanıyacaklar. Sıklıkla çöken toprak yollar geçir verirse bir kamyonetin kasasında saatlerce yol gidecekler. Köyler, kasabalar tek 
tek kaybolacak. Dağlar aşılacak, nehirler geçilecek ve sonunda yol onları şehre götürecek" (10. Bölüm, 15.56).
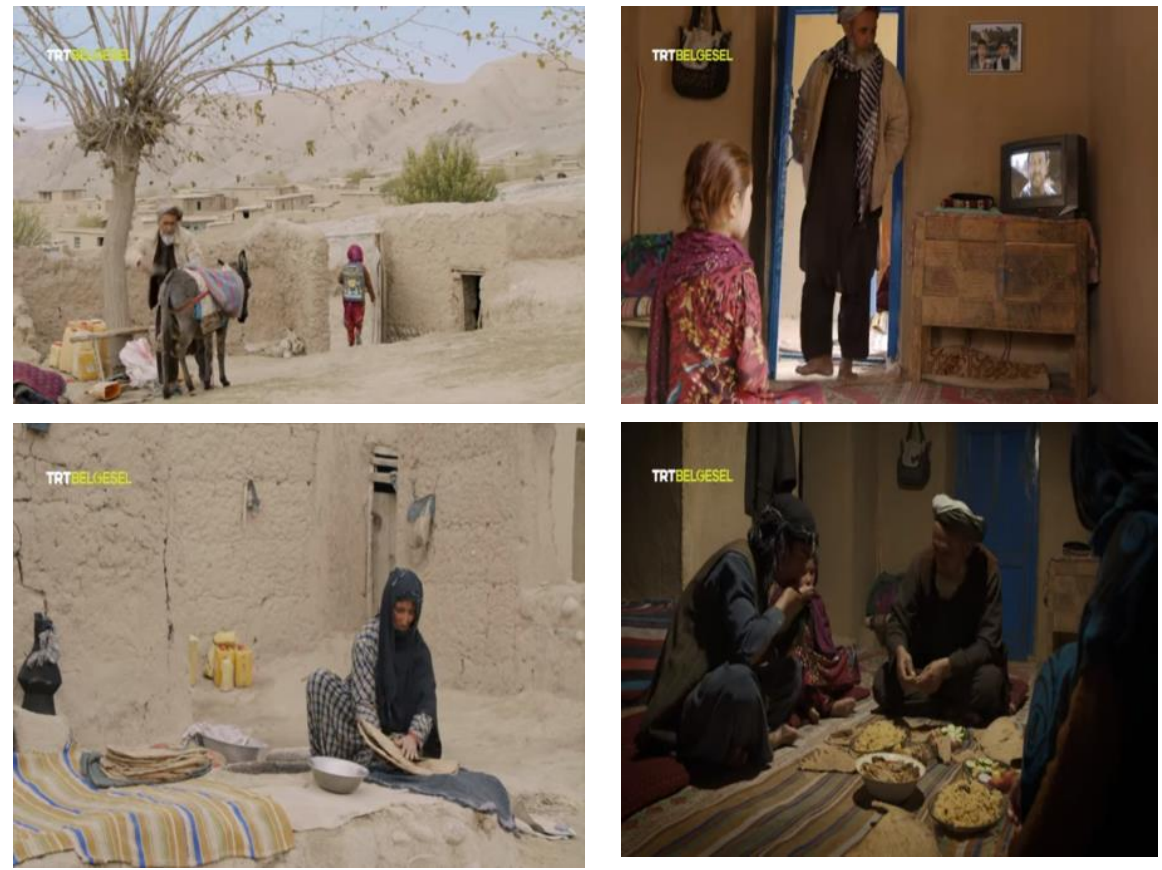

Şekil 10. Beklenen Gün

"İlk fotoğrafı çekildiğinde bir kız, âlemin renklerine bir renk katmak istediğinde kimseden habersiz, gülmek en çok ona yakıştı̆̆ında tam da o anda içi içine sığmadğında dünyada bir şey olur. Nasıl da akıl almaz bir sırdır o. Küçük bir kalbe, sonsuz sevgi, sinırsız bir sevgi nasıl sı̆̆ar. Azizullah, yıllar önce oğlunun öldüğ̈̈ o yere nişaneyi diktiğinde bir gün Hatice' nin büyüyüp oyunlar oynayacağım düşünmüş̧ müdür? Peki, bir taş iki dünya arasında nasıl köprü olabilir. Belki de beklenen gün o kadar uzak değildir. Kim bilir. Bu, daha doğmadan babasını kaybeden küçük bir kızın hikâyesi. Bu hesaplaşacă̆̆ günü sabırla bekleyenlerin hikâyesi. Bu Afganistan'da yaşayan yüzbinlerce çocuğun hikâyesi" (10. Bölüm, 19.49).

Tarihte savaşlar, işgaller gibi toplumsal olayların sonrasında meydana gelen travmatik yaşantılar, her ne kadar aile kurumu için doğrudan bir tehdit unsuru olarak görünse de toplumsal ve tarihsel dünyanın inşasını mümkün kılan insanların, bu koşullar altında bile aile olmanın bilincini yitirmedikleri 
ve aile kurumunu korumak adına üstlendikleri rolleri yerine getirme çabası içinde oldukları bu belgeselde gözlenmektedir.

Büyük Dua (Bölüm 11): Büyük Dua, savaş ve darbe sebepleriyle ebeveynlerini (babalarını) yitirmiş olan Gina ve Alpaslan'ın iki kıtayı bir mektupla ve aynı hikayeyle birleştiren yaşantılarını konu almaktadır. Bu bölüm, çocuk hizmetleri, darbe, tarih, haberleşme, mektup, duygular ve dil ana temaları üzerine şekillenmektedir.
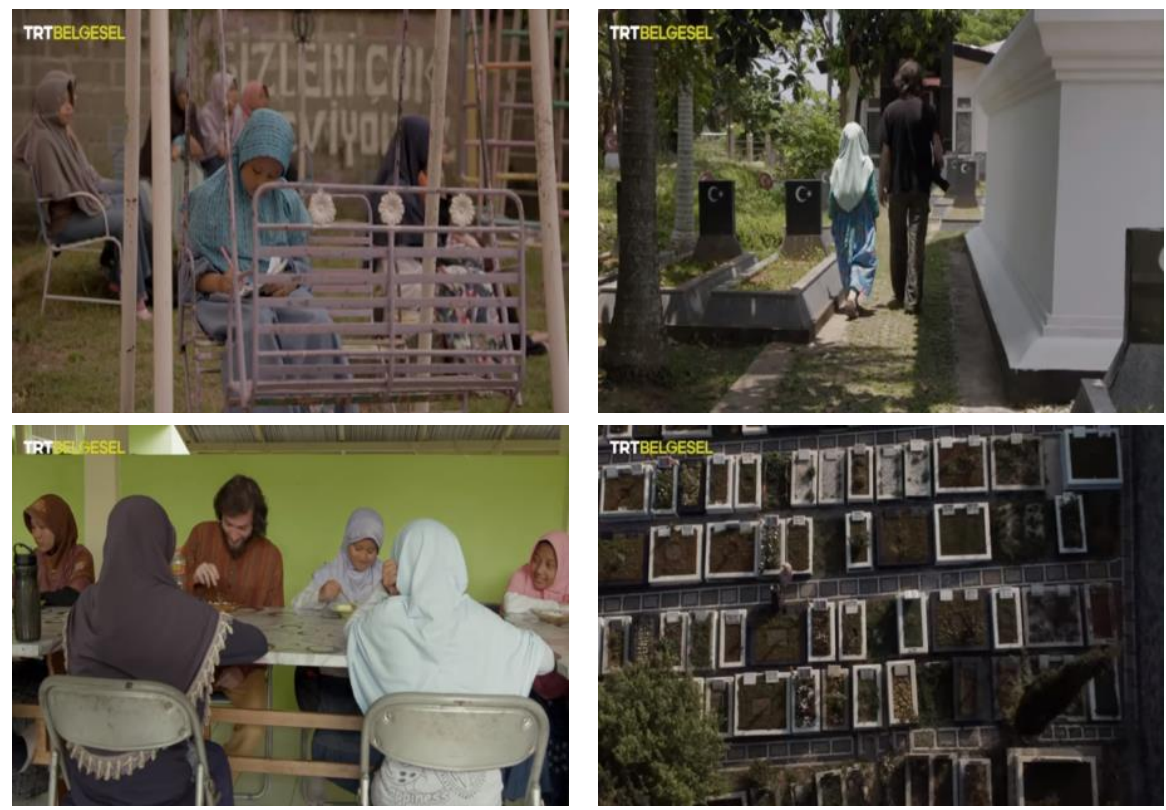

Şekil 11. Büyiuk Dua

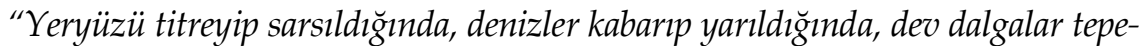
leri aşıp şehri vurduğunda burada yaşayanlar için felaket kaçınılmazdı. Endonezya'nın Ace bölgesi, büyük bir afetle yıkıma uğ ramış tusunami yüz yetmiş bir insanın ölümüne neden olmuştu. Aradan yıllar geçti ve felaket günlerinde atılan tohum filizlenip yeşerdi. Böylece birbirine uzak iki diyar arasında güçlü bir bağ kuruldu. Dillerin, renklerin farkl fakat gönüllerin bir olduğu kardeşlik bağı. (11. Bölüm, 26.18). Bu birbirinden çok uzak olsalar da kalpleri birlikte çarpan büyük bir ailenin hikayesi. Bu kabul olunmuş duanın hikayesi. Bu bizim hikayemiz" (11. Bölüm, 2.15). 
Gina, her sabah yetimhanedeki diğer çocuklarla birlikte okula gitmek için Açe'den yola çıkmaktadır. Her gün aynı yere oturup babasını düşünmektedir. Ebeveynleri olmadan yaşamın zorluklarını deneyimleyen ve birbirlerinden uzak iki ayrı diyarda yaşayan Alpaslan ve Gina'nın hikayeleri kıtaları birleştirmektedir.

“Sekiz yaşındaki Gina sınıfinın en başarılı öğrencilerinden biri. Ancak diğer çocuklardan tek farkı bu değil. Her gün okula yetimhaneden geliyor. Okumayı resim yapmayı ve mektup yazmayı seviyor. Yazdığı mektuplar kıtaları ötesinde başkalarının hayatını değiştiriyor. Derler ki bir kelebeğin kanat çırpışları başka bir kıtada firtınalara sebep olabilir. Peki bir mektup neler yapabilir. Pencereden bakttğında gelmeyecek olsa da, sımsıkı sarılamayacak olsa da sevgiyle dünya döndükçe arayış hiç bitmeyecek. İlk yürüyüşünü hatırlayan, ilk gülüşün için sevinçle ağlayan bu adamın mirası seni yola düşürmeye devam edecek. Şimdi yeniden düşün seni bu topraklara getiren şey neydi. Beş asır önce ayn yolu kimler, neden gelmişti?" (11. Bölüm, 11.06).

"Bundan yaklaşık beş yüz yıl önce buraya (Endonezya) Osmanl donanması da gelmişti. Onlarn yola düşüren şey de bir mektuptu. Mektupta Açe sultanı Portekiz işgaline karşı Osmanlı sultanından yardım istiyor ve bu topraklarn da Osmanlı yurdu olduğunu söylüyordu. Aradan beş asir geçtikten sonra bir genç (Alpaslan) ayn topraklarda yürüyor. Tarihin mirası onu hiç yalnız bırakmıyor" (11. Bölüm, 14.34). "Bazen ders çalı̧ırken dalıp uzak diyarlara gidiyorum. Bir bilseniz nereleri geziyorum. Sonra bir bakıyorum ayn yerdeyim. Dünyayı gerçekten gezip görmek isterdim... Bazen babamı çok özlüyorum. Beni okula onun götürmesini isterdim. Derslerimde ne kadar başarll olduğumu görmesini isterdim" (Gina, 11. Bölüm, 10.45).

Görüldüğü gibi, bu ifadeler iletişimin hangi araçlarla sağlanırsa sağlansın toplumsal etkileşim boyutundaki etkisinin gücünü ortaya koymaktadır. Birbirinden farklı toplumlar her ne kadar farklı kültürlere ve farklı dillere sahip olsalar da insanların tüm toplumlarda ortak değer olan "Aile Olmak" konusundaki hassasiyetleri belgeselde simgesel olarak tüm duygusal/manevi/içsel davranış örüntüleriyle sanatsal boyutta izleyenlere sunulmuştur.

Belgesel serisinin final kısmını oluşturan bu bölümde tıpkı diğer bölümlerde de yansıtıldığı gibi, yaşamın tüm tehditlerine rağmen aile kurumunu korumaya yönelik ciddi çabalar yer almaktadır. Böylelikle, güçlü aile yapısını korumanın ve toplumda ailenin çözülmesi ve dağılmasına yönelik tehditlere karşı önlem almanın önemi ortaya çıkmaktadır (Can, 2014, s.78). 


\section{Sonuç}

Bu çalışmada, aile kurumuna yönelik farklı kültürel deneyimler, TRTBELGESEL'de yayınlanmış olan "Aile Olmak" başlıklı belgesel serisi örneği üzerinden sosyolojik olarak incelenmektedir. TRTBELGESEL'de yayınlanan ve on bir bölümden oluşan "Aile Olmak" adlı belgesel serisi, tarihsel süreç boyunca gündelik yaşamın tüm zorluklarına rağmen onlarla mücadele eden insanları, onların yaşam deneyimlerini ele alan ve sosyolojik olarak literatüre katkı sunacağı düşünülen, konusu itibariyle araştırılması ve incelenmesi elzem görülen niteliksel bir görsel materyaldir. Her bölüm, farklı kültürlerden, karakterlerden ve hikâyelerden derlenerek gerek görsel gerek işitsel gerek sözsel ve gerekse de anlatısal olarak sembolik anlamda bir mozaik sunmaktadır. Gündelik yaşamın, farklı toplumlarda ne şekilde ve nasıl deneyimlendiğinin anlatıldığı bu belgesel serisinde, her konu toplumsal gerçekliği farklı yönleriyle anlamlandırmamızı, yorumlamamızı ve değerlendirmemizi sağlamaktadır. Belgesel'in, her şeyden önce ve en önemlisi de niteliksel olarak bu farklı kültürler ve farklı yaşantı deneyimleri üzerinden insan olma kabiliyetini unutmadan "empati" kurabilme, toplumsal gerçeklik ve gündelik yaşama ilişkin farkındalık oluşturma amacı taşıdığını söylemek mümkün olmaktadır. 


\title{
EXTENDED ABSTRACT
}

\section{Sociological Analysis of Threats Against Family Institution in Terms of Different Cultural Experiences}

\author{
Ayşegül Demir \\ Sinop University
}

In this study, it is aimed to examine the sociological analysis of the threats against the family institution in terms of different cultural experiences, through the example of the documentary series titled "Being a Family" published in TRTBELGESEL. In this study, the concepts of "everyday life" and culture of the Social Constructive Approach have been dealt with as the focal point in theory.

Qualitative research methods were used in the study, as it was aimed to deeply understand the different cultural experiences of threats to the institution of the family and different dynamics in daily life with various aspects. When the technological possibilities are considered, the audiovisual evidence, which is a qualitative research example and which is behind social phenomena, should be monitored, used and analyzed in document analysis method. In this respect, audio / visual categories mediate the researcher to contribute directly or indirectly to the document. During the use of documents, the researcher determines its priority and then configures the data accordingly according to distinctions and classifications (Seggie and Bayyurt, 2015, p.284).

The findings of the study include the findings of the data obtained from eleven documentary series called "Being a Family" published in TRTBELGESEL. The first subject of the study, New Heroes, "expatriate"; Under the Olive Trees, which constitutes the second subject, Refugee, "Space, Disability, Trauma, Health-Malnutrition"; In Pursuit of Dreams that constitutes its third subject; "Unqualified Labor Force"; The fourth subject is "Where the Desert Begins", "Settlement-Transportation, Drought, Agriculture-Livestock, Settlement-Transportation, Health-Aging, Craft-Capital, Education / Opportunity Inequality"; The fifth subject of the City's Last Residents, "War, Migration, 
Communication"; Happy Holidays, "Imperialism, Tourism, Cultural Corruption, Values, Inequality"; Two Stories On Water, "Fish Farming, Capitalism, Everyday Life", which constitutes its seventh subject; Desert Travelers, which constitute the eighth subject, "Childhood", the ninth subject of the Steppe Watchers, "Nomadism, City, Traditions"; The tenth subject, the Expected Day, "Occupation, Poverty, Exploitation"; The eleventh subject, Great Dua, includes the main themes of "Child Services, Coup-History, Communication / Letter, Feelings-Language". The experiences of people living in different countries about the family life in the documentary are quite meaningful in terms of providing an awareness to the society we live in.

Symbolically, in the documentary "to be a family", a feast of indications about the family "life" styles of societies living in different cultures is presented, both visually and audibly. When it comes to the content of the documentary series, it is possible to interpret, describe, interpret and evaluate all social, economic and historical processes in daily life, from the streets to global processes, through indicators. Each episode presents a mosaic in a symbolic sense both visually, auditory, verbal and narrative, compiled from different cultures, characters and stories.

In this documentary series, where daily life is experienced in different societies and how it is experienced, each subject enables us to understand, interpret and evaluate social reality from different aspects. It is possible to say that the documentary aims to "empathize", create awareness about social reality and daily life without forgetting the ability to be human through these different cultures and different life experiences, first of all and most importantly, qualitatively.

\section{Kaynakça / References}

Berger, P. L., ve Luckmann, T. (2008). Gerçekliğin sosyal inşası bir bilgi sosyolojisi incelemesi. (V. S. Öğütle, Çev.). İstanbul: Paradigma Yayınları.

Bilgin, N. (2006). Sosyal bilimlerde içerik analizi teknik ve örnek çalışmalar. Ankara: Siyasal Kitabevi.

Can, İ. (2014). Moderniteden postmoderniteye ailenin ontolojisi ya da modern çekirdek aile çerezleşiyor mu?. M. Aydın (Ed.). Aile Sosyolojisi Yazıları. İstanbul: Açllımkitap.

Canatan, K. (2013). Klasik Türk düşüncesinde ailevi değerler. K. Canatan ve E. Yıldırım (Ed.). Aile Sosyolojisi. İstanbul: Açlımkitap. 
De Landa, M. (2006). Çizgisel olmayan tarih bin yılın öyküsü. (E. Kılıç, Çev.). İstanbul: Metis Yayınları.

Demir. A. (2020). Afetlerde dezavantajlı gruplar. İ. Can (Ed.). Afet Sosyolojisi. Konya: Çizgi Kitabevi.

Gardiner, M. (2016). Gündelik hayat eleştirileri. (D. Özçetin, B. Taşdemir ve B. Özçetin, Çev.). Ankara: Heretik Yayınları.

Lefebre, H. (2007). Modern Dünyada gündelik hayat I. (I. Gürbüz, Çev.). İstanbul: Metis Yayınları.

Mayring, P. (2011). Nitel sosyal araştırmaya giriş. (A. Gümüş ve M. S. Durgun, Çev.). Ankara: BilgeSu.

Mcfarlane, C. (2013). İlişkisel sosyoloji:Teorik anti-hümanizm ve insan-dışı meselesi. C. Powell ve F. Dépelteau, (Ed.). Ilişskisel Sosyoloji. Ankara: Phoenix Yayınevi.

Önür, N. (2005). Toplumsal ilişkiler sürecinde iletişim. S. Güçlü. (Ed.). Kurumlara Sosyolojik Bakış. İstanbul: Birey Yayıncılık.

Özyurt, C. (2013). Çocukluk sosyolojisi. K. Canatan ve E. Yıldırım (Ed.). Aile Sosyolojisi. İstanbul: Açılımkitap.

Sarı, Ö. (2013). Aile kurumu ve ailenin tanımı. M. Aydın (Ed.). Sistematik Aile Sosyolojisi. Konya: Çizgi Kitabevi.

Searle, J. R. (2005). Toplumsal gerçekliğin inşası. (M. Macit ve F. Özpilavcı, Çev.). İstanbul: Litera Yayıncılik.

Seggie, F. N. ve Bayyurt, Y. (2015). Nitel Araştırma Yöntem, Teknik, Analiz ve Yaklaşımlar. Ankara: Anı Yayıncılık.

Subaşı, N. (2014). Toplumsal değişme, aile ve yeni risk alanları. M. Aydın (Ed.). Aile Sosyolojisi Yazıları. İstanbul: Açılımkitap.

Toksoy, N. G. (2019). Görsel sosyolojik saha araştırmaları ve fotoğraf. Sosyal Bilimler Dergisi, 6(41), 362-373.

Trt Belgesel (2019). Aile Olmak. [Videoblog]. https://www.trtbelgesel.com.tr/kultur-antropoloji/aile-olmak adresinden erişilmiştir.

\section{Kaynakça Bilgisi / Citation Information}

Demir, A. (2020). Aile kurumuna yönelik tehditlerin farklı kültürel deneyimler açısından sosyolojik incelemesi. OPUS-Uluslararası Toplum Araştırmaları Dergisi, 16(32), 5422-5450. DOI: 10.26466/opus.812891 